\title{
Assessment results (2015-2018) of re-established poached cycad trees in Addo Elephant National Park, Eastern Cape, South Africa
}

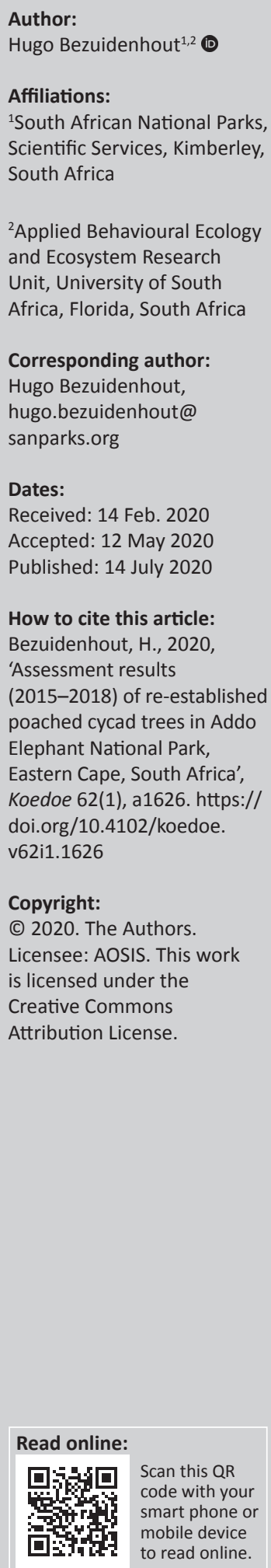

\section{Introduction}

On 12 February 2015, the South African Police Services confiscated 39 Encephalartos longifolius plants (Thunberg's cycad or Zuurberg cycad) and nine Encephalartos lehmannii (Karoo cycad) plants illegally removed from the wild on a farm adjacent to the Darlingtondam section of Addo Elephant National Park (AENP). The confiscated plants were delivered to AENP on Saturday, 14 February 2015 (Figure 1).

According to the 1997 and 2006 International Union for Conservation of Nature Red List of Threatened plant species, $82 \%$ of the world's cycads are listed as threatened and, thus, are facing a major extinction crisis (Singh 2012). Some species are dying out naturally, but the major extinction contributing factor is human activities (Donaldson 2003). In South Africa, cycads were declared 'Specially Protected Plants' in 1971 in the Transvaal (Van der Walt 2014) and cycad owners had to apply for a permit. Since then, all other provinces have implemented strict protective laws and heavy penalties were laid down by the Nature Conservation Ordinances of each province (Singh 2012).

Cycads (Encephalartos) are known as the most primitive living seed-bearing plants belonging to an ancient order of Cycadales, which flourished in the Carboniferous period about 100 million years ago (Singh \& Campbell 2011). Cycads belong to a group of plants known as gymnosperms (plants which bear naked seeds) and their reproductive organs are produced in cones (Giddy 1974). These cycad plants have survived for over 150 million years with little change in their basic structure, and neither fire nor drought presents any real threat to their survival (Giddy 1974). Cycads are dioecious, meaning that male and female cones occur on separate plant individuals and, in order for pollination to take place, male and female plants have to cone at the same time and be close to one another (Giddy 1974). South Africa is considered to be one of the centres of cycad diversity, hosting more than half of the known Encephalartos species in Africa, with $76 \%$ of these species endemic to South Africa. Sadly, $78 \%$ of the South African Encephalartos species are threatened with extinction (Van der Walt 2014).

According to Van der Walt (2014), Encephalartos species are collectively the most threatened plant species group in South Africa today, and also the most threatened group of plants in the world (Department of Environmental Affairs 2015). Twelve of the 37 (32\%) Encephalartos species are regarded as Critically Endangered, whilst an additional three are already considered Extinct in the wild. There are less than 100 plants left in the wild for seven of the Critically Endangered species, four species of which are on the brink of extinction. A further four Encephalartos species are regarded as Endangered. The predominant threat facing cycads is the ongoing illegal removal of adult plant individuals from wild populations to meet the current demand for large cycads for private collections and for landscaping purposes. Recently, cycads have also been poached for use in muthi-markets, where these plants are used for traditional purposes. Adult plant individuals are also highly valued as parental stock for seedling propagation for both the domestic and international cycad trade. All species of the genus Encephalartos are included in Appendix I of the Convention on International Trade in Endangered Species of Wild Fauna and Flora (CITES) (Bezuidenhout \& Hofmeyr 2016).

A key mandate for the South African National Parks (SANParks) is to continue contributing to the representation of threatened ecosystems and plant species in a national protected area network. The South African National Parks' mandate also extends to ensure conservation and protection of cycads under their jurisdiction (Bezuidenhout et al. 2017; Department of Environmental Affairs 2015; 

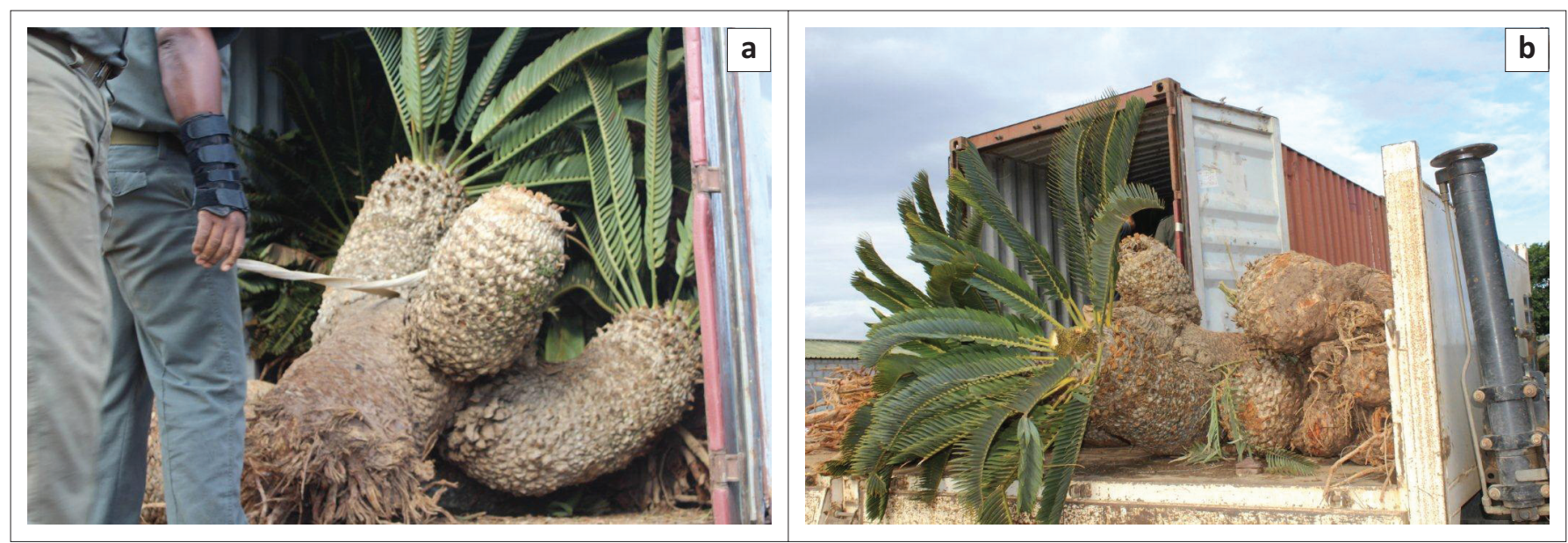

Source: Photo courtesy of John Adendorff

FIGURE 1: Cycad plants recovered from poachers. (a) and (b) E. longifolius.

Staatskoerant 2017). The complex nature of the supply and demand of cycads has led to these plants becoming a human dependent for survival and persistence in its natural habitat (Van der Walt 2014). South African National Parks therefore decided to assist in the re-establishing of the confiscated plants in the AENP.

Donaldson (1995) noted that conservation practitioners might base their actions on generalisations and assumptions, in the absence of detailed information on how cycad species respond to certain actions. Donaldson (1995) classified both cycad species (E. lehmannii and E. longifolius) as Type 2, namely as a persister/reproducer, with the following life history traits: (1) aerial stems reaching several meters in height with several basal suckers; (2) a single (often large) cone per plant, whilst the environment of these cycads correlate well with an arid environment of fire climax vegetation and a high incidence of mast seeding in fire climax vegetation. A literature review revealed no published information on how unearthed planted cycads have responded to being re-established. Partly related to this subject, Boyd (1995) described five ex situ conservation measures in the translocation or relocation of several cycad plant species that provincial conservation authorities were involved with, with mixed success results. The long-term feasibility of reintroduction and translocation has not been determined, as it involves long-term monitoring and active management (Boyd 1995). Cousins and Witkowski (2017) noted that:

[I]t appears that most African cycad species are fire-tolerant, and that the fine-leaved, woolly-coned Encephalartos species generally show the most pronounced positive response to fire, the phenomenon of fire-stimulated leaf and cone production is still poorly understood, and requires further study. Further investigation is needed to determine the actual fire-related cues that trigger leaf and cone production. (p. 166)

The main aim of this paper is, therefore, to document the actions taken to re-establish the confiscated cycad plants (E. lehmannii and E. longifolius) in two habitat sites: (1) the AENP gardens; and (2) in the Zuurberg section of AENP, where a natural fire regime exists.

\section{Methods}

The species were identified, numbered, sexed (if possible), and the plant length, stem diameter, injury (\%), cones absent/present, leaves absent/present, single or multistemmed were recorded. Treatment of the cycads consisted of removing all of the leaves and cones as well as chemical treatment. The cycad individuals were chemically treated with Dynaroot hormone powder (no. 2) (to stimulate new root growth), Bravo 720 with chlorothalonil (active ingredient mostly to prevent fungal diseases attacking the stressed cycads), $20 \mathrm{~mL}$ Chloropiriphos to kill any insects, and Blue tree seal (to enhance recuperation after replanting by protection against fungi, and to keep roots healthy for maximum water absorption). The cycads were replanted between 23-26 February 2015 in accordance with guidelines proposed by Bezuidenhout (2015).

In March 2018, all of the localities were re-visited and all of the plants were re-assessed. A photograph of each individual was taken. The health of the individual was assessed in three categories: (1) the presence or absence of leaves (healthy with $>4$ leaves), (2) dormant without any damage (standing with firm stem and crown, but no leaves present), and (3) dead by being damaged and/or lying on the ground or nothing left (no leaves, not standing, disintegrated stem most of it not present [ $>75 \%$ ] or pieces of stem lying around at the locality). All of the cycads were checked thoroughly for injuries and insects that might have a negative impact on their condition and recovery.

\section{Sites}

After discussions, consensus was reached that, as a result of (1) time constraints, (2) lack of man power, (3) costs, (4) original site of the cycads being outside of the AENP, (5) inhospitability of original site and difficulty to reach the terrain, and (6) ease of plot-established monitoring, the recovered cycad individuals would be planted in the Zuurberg section and gardens of the AENP offices. Four possible sites for planting the E. longifolius (Thunberg's or 
Zuurberg cycad) cycads in the Zuurberg section of AENP were identified. The few individuals of E. lehmannii (Karoo cycad) were planted in one garden in AENP, whilst four badly-injured E. longifolius were planted in another section of the gardens in AENP.

\section{Ethical consideration}

I confirm that ethical clearance was not required for the study.

\section{Results and discussion}

In total, 39 E. longifolius cycad plants were replanted; six of these were young individuals, where either suckers or branches had broken off during handling. The sex ratio was eight female plants to 17 males. Because of the absence of cones, the sex of the other 14 plant individuals could not be determined at the time. Twenty of these cycads were more than $3 \mathrm{~m}$ tall, nine were about $2 \mathrm{~m}$ tall, four about $1 \mathrm{~m}$ tall and the other six were small individuals $(0.2 \mathrm{~m}$ to $0.4 \mathrm{~m})$. Thirtytwo cycads were single stemmed and one was multibranched, and six young cycad suckers were recorded (Table 1) (Bezuidenhout 2015).

All of these cycads were in fairly good condition even though they had been handled roughly. Bruises were noted on the individual cycads, indicating that plants were pushed over by a tractor and then pulled across rocks and hard soil surfaces using ropes. Termite activity was noticed on one of the cycads and it was treated.

Nine E. lehmannii individuals were planted, including four young individuals (unknown sex) derived from suckers or branches that had broken off during the handling of these plants. The sex ratio for the five adult individuals was one male, one female and three of unknown sex. The height classes of the nine individuals comprised one that was approximately $2 \mathrm{~m}$ tall, four about $1 \mathrm{~m}$ tall, and the other four young individuals being $0.2 \mathrm{~m}$ to $0.4 \mathrm{~m}$ tall (Table 1) (Bezuidenhout 2015).

\begin{tabular}{|c|c|c|}
\hline Variable & Encephalartos lehmannii & Encephalartos longifolius \\
\hline \multicolumn{3}{|l|}{ Sex ratio } \\
\hline Male & 1 & 17 \\
\hline Female & 1 & 8 \\
\hline Undetermined & 7 & 14 \\
\hline Total individuals & 9 & 39 \\
\hline \multicolumn{3}{|c|}{ Height classes (m) } \\
\hline$>3$ & 0 & 20 \\
\hline$>2$ & 1 & 9 \\
\hline$>1$ & 4 & 4 \\
\hline$>0.2$ & 4 & 6 \\
\hline \multicolumn{3}{|l|}{ Stemmed } \\
\hline Single & 3 & 32 \\
\hline Multi-branched & 2 & 1 \\
\hline Suckers & 4 & 6 \\
\hline
\end{tabular}

\section{Addo Elephant National Park gardens}

The individuals that were selected to be planted in one of the AENP gardens were either E. lehmannii or could not be identified because of the absence of leaves. Six suckers were also planted in the Aloe species rocky garden. In a separate second AENP garden, four individuals of E. longifolius were planted. All four individuals were seriously damaged either by fire scars or from being injured when removed from the veld.

Five of the adult monitored individuals had more than four leaves (Figure 2), and two had suckers bearing leaves. From the six individual suckers that were planted in the Aloe species dominated garden, four had healthy leaves whilst two had died. Three adult cycad individuals are standing but without leaves, whilst four are dead and have been removed (Table 2).

After 3 years, we concluded that of the 18 cycad individuals planted in the gardens of AENP, nine are in good condition with leaves (50\%) and six are dead (33\%). Because cycads can remain dormant for a long time without bearing leaves, it is difficult to assess whether individuals are dead or alive when the stem is still in seemingly good condition. The condition of three of the above-mentioned cycads could not be determined accurately and was recorded as standing (17\%).

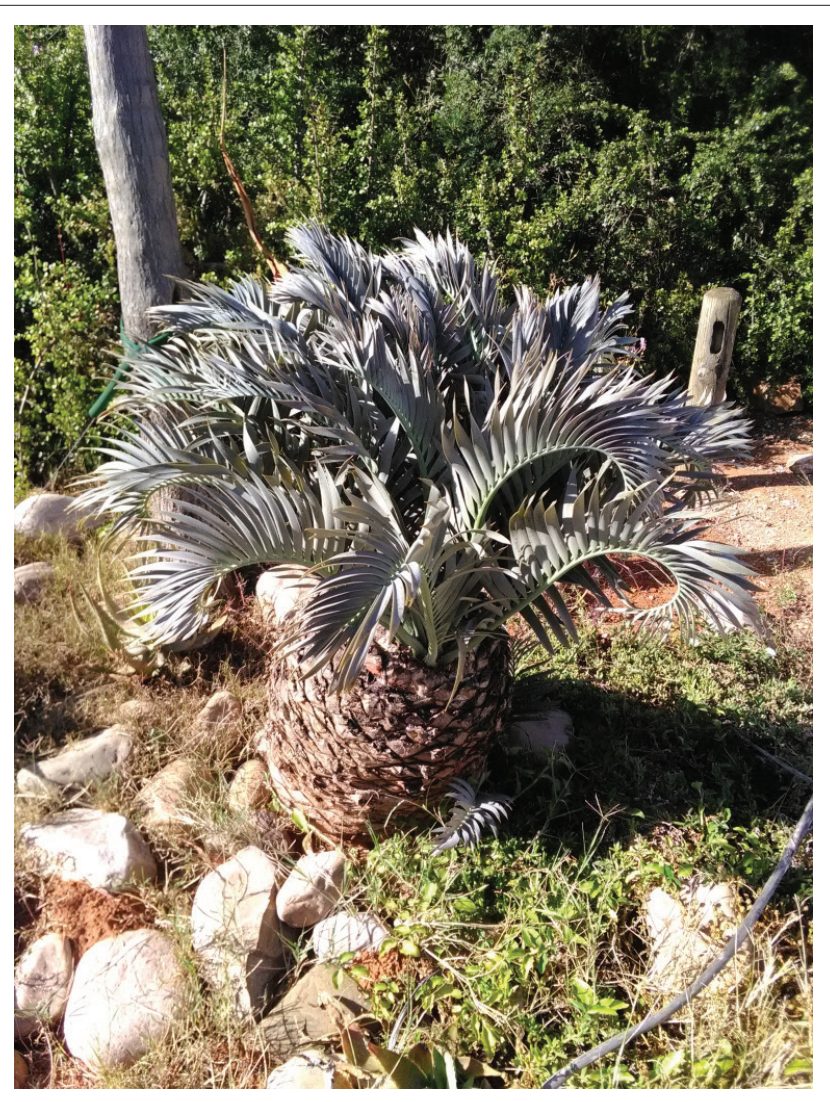

FIGURE 2: Healthy planted individual Encephalartos lehmannii cycad in Addo Elephant National Park garden. 
TABLE 2: Monitoring result for planted cycads in gardens of Addo Elephant National Park.

\begin{tabular}{|c|c|c|}
\hline $\begin{array}{l}\text { Plant } \\
\text { number }\end{array}$ & Condition when recovered 2015 & Condition monitored 2018 \\
\hline 14 & Sucker without leaves & Healthy with leaves \\
\hline Co 02 & Sucker without leaves & Healthy with leaves \\
\hline Co 03 & Sucker without leaves & Healthy with leaves \\
\hline Co 04 & Sucker without leaves & Healthy with leaves \\
\hline Co 05 & Sucker without leaves & Dead removed from garden \\
\hline Co 06 & Sucker without leaves & Dead removed from garden \\
\hline 10 & Healthy with leaves & Healthy with leaves \\
\hline 11 & Without leaves, injured & Standing without leaves \\
\hline 8 & Without leaves, Injured & Dead removed from garden \\
\hline 37 & $\begin{array}{l}\text { Healthy with leaves and number } \\
\text { of suckers }\end{array}$ & Healthy with leaves and suckers \\
\hline 6 & Healthy with leaves & Dead removed from garden \\
\hline 7 & Healthy with leaves & Healthy with leaves \\
\hline 18 & Healthy with leaves & Healthy with leaves \\
\hline 13 & Healthy with leaves & Standing without leaves \\
\hline 4 & With leaves but badly injured & Dead removed from garden \\
\hline 21 & With leaves but badly injured & Dead removed from garden \\
\hline 22 & With leaves but badly injured & Standing without leaves \\
\hline 9173 & $\begin{array}{l}\text { With leaves and one sucker but } \\
\text { badly injured }\end{array}$ & Healthy with leaves and sucker \\
\hline
\end{tabular}

Because the habitat of this locality is a human-made garden, these cycads receive more water on a regular basis, the soil was disturbed (construction of building) and drainage might not be ideal compared to the Zuurberg localities. Despite these, the overall result indicates a significantly positive response. Limited impact by wildlife was noted.

\section{Addo Elephant National Park Zuurberg section}

All of the cycads that were replanted in the Zuurberg section were E. longifolius individuals. Care was taken to plant cycads of different sexes in one stand or group. According to advice from experts, these cycads were planted $8 \mathrm{~m}-10 \mathrm{~m}$ apart (Cousins \& Witkowski 2017; Donaldson 1995). Four sites were used for planting cycads. A few months after planting, one individual showed new leaf growth and some coned. Ants were observed at one individual, but otherwise all of the cycad individuals appeared to be in good condition (Bezuidenhout 2015).

\section{Site 2}

At site 2, six cycad individuals were replanted in February 2015. When inspected in 2018, one adult individual was recorded to have more than four leaves and was in a healthy condition. Fire scars were noted on the leaves and stem as a result of a fire during the previous year. One individual was still in an upright position with a sucker that might still grow, but showed extensive damage to the main stem caused by baboons. One other individual was recorded as dormant (still standing, but without leaves). Three individuals had died,
TABLE 3: Monitoring result for replanted cycads in Zuurberg section, Addo. Site / Plant Condition when recovered 2015 Condition monitored 2018 number

\begin{tabular}{|c|c|c|}
\hline \multicolumn{3}{|c|}{ Site 2} \\
\hline 40 & Healthy with leaves & $\begin{array}{l}\text { Standing without leaves, baboon } \\
\text { impact }\end{array}$ \\
\hline 42 & Healthy with leaves & $\begin{array}{l}\text { Standing without leaves with a } \\
\text { sucker }\end{array}$ \\
\hline 32 & Healthy with leaves & $\begin{array}{l}\text { Dead, top half away from the } \\
\text { planted area }\end{array}$ \\
\hline 38 & Healthy with leaves & $\begin{array}{l}\text { Standing with leaves, fire scars on } \\
\text { leaves }\end{array}$ \\
\hline 41 & Healthy with leaves & Dead, nothing left \\
\hline 34 & Healthy with leaves & Dead, nothing left \\
\hline \multicolumn{3}{|c|}{ Site 3} \\
\hline 28 & Healthy with leaves & Healthy with more than 20 leaves \\
\hline 29 & Healthy with leaves & Dead, nothing left \\
\hline 39 & Healthy with leaves & $\begin{array}{l}\text { Standing - lost its leaves, fire scars } \\
\text { and baboon impact }\end{array}$ \\
\hline 27 & Healthy with leaves & Dead, nothing left \\
\hline 31 & Healthy with leaves & Healthy with 18 leaves \\
\hline 13 & Healthy with leaves & Healthy with more than 20 leaves \\
\hline 51 & Healthy with leaves & $\begin{array}{l}\text { Dead, uprooted and lying on its } \\
\text { side }\end{array}$ \\
\hline 33 & Healthy with leaves & $\begin{array}{l}\text { Dead, partly standing, with hole } \\
\text { in upright trunk }\end{array}$ \\
\hline \multicolumn{3}{|c|}{ Site 4} \\
\hline 19 & Healthy with leaves & Dead, uprooted and lying on its side \\
\hline 20 & Healthy with leaves & Standing without leaves \\
\hline 16 & Healthy with leaves & Dead, nothing left \\
\hline 36 & Healthy with leaves & Dead, nothing left \\
\hline 26 & Healthy with leaves & Dead, nothing left \\
\hline 24 & Healthy with leaves & Dead, nothing left \\
\hline 36 & Healthy with leaves & $\begin{array}{l}\text { Uprooted and lying without } \\
\text { visible injury }\end{array}$ \\
\hline 25 & Healthy with leaves & $\begin{array}{l}\text { Standing with leaves, with ants on } \\
\text { the leaves }\end{array}$ \\
\hline \multicolumn{3}{|c|}{ Site 5} \\
\hline 3 & Healthy with leaves & $\begin{array}{l}\text { Uprooted and lying without } \\
\text { visible injury }\end{array}$ \\
\hline 11 & Healthy with leaves & Healthy with five leaves \\
\hline 2 & Healthy with leaves & Dead, nothing left \\
\hline 10 & Healthy with leaves & $\begin{array}{l}\text { Standing without leaves, } \\
\text { impacted by baboons }\end{array}$ \\
\hline 12 & Healthy with leaves but ants noted & Dead, nothing left \\
\hline 9 & Healthy with leaves & Dead, nothing left \\
\hline 1 & Healthy with leaves & Dead, nothing left \\
\hline 5 & Healthy with leaves & Dead, nothing left \\
\hline
\end{tabular}

leaving either no trace of stems, or the remains of stems having been scattered in the veld (Table 3 ).

It could thus be concluded that of the six cycad individuals replanted at site 2 , one was in good condition bearing leaves $(17 \%)$, two were inconclusive regarding their condition $(33 \%)$, and three were dead (50\%).

\section{Site 3}

Eight cycad individuals were replanted in February 2015 at site 3. When monitored in 2018, three adult individuals were recorded to be in a good condition bearing leaves (more than four). One individual was previously recorded with leaves (no leaves noted in 2018) but even though it was still standing, scars and damage caused by baboons were clearly evident at the time of the survey. Four individuals had died leaving either no trace, or the remains of stems were scattered in the veld (Table 3). 
It could thus be concluded that of the eight cycad individuals replanted at site 3, three appeared healthy bearing leaves (38\%), one's condition could not be determined (dormant) $(12 \%)$, and four had died (50\%).

\section{Site 4}

Eight cycad individuals were replanted in February 2015 at site 4 . When monitored in 2018, one adult individual was recorded with more than four leaves. The particular individual, however, did not seem to be in good condition, with ants noted on the stem and leaves. One individual, was dormant (standing without leaves) but the stem looked healthy and intact. Two individuals were uprooted and might still grow from this horizontal position. Four individuals were recorded dead and either nothing could be found or loose remains of stems were scattered in the veld (Table 3). The baboons impacted on these cycads more than at the other three sites, because it appears to have been planted on their daily foraging route.

It could thus be concluded that of the eight cycad individuals replanted at site 4 , one of them was healthy with leaves (12\% of the planted cycad individuals), for three the condition could not be determined (38\%), and four were dead (50\%).

\section{Site 5}

Eight cycad individuals were replanted in February 2015 at site 5 . The monitored result was one adult individual with five leaves recorded, however, this individual did not look healthy. One individual was recorded as dormant (still standing but without leaves) and more than $30 \%$ of the stem had been damaged. One individual was uprooted but might still grow from its current position lying on the soil surface. Five cycad individuals were recorded as dead and either nothing could be found or loose remains of stems were scattered in the veld (Table 3).

It could thus be concluded that of the eight cycad individuals replanted at site 5 , one was healthy with leaves (12\%), for two the condition could not be determined (25\%), and five were dead $(63 \%)$.

Final results of the March 2018 survey indicated that of the 48 cycad individuals (including broken-off additional suckers), $27 \%$ were in a good healthy condition and bearing leaves. Twenty-seven percent were standing without leaves but still had the potential to grow (dormant). Currently, $46 \%$ of the planted cycads have died and have either been removed or loose remains of stems have been found (Table 4).

Some localities and sites showed more success than others; for example, $43 \%$ of the cycad individuals planted in February 2015 at the AENP garden looked healthy with leaves, whilst at sites 4 and 5 in the Zuurberg section, only $12 \%$ of the replanted individuals had leaves (Tables $1 \& 2$ ). An interesting observation was that fire actually stimulated five cycads, which had been
TABLE 4: The monitoring results of all the planted cycads in Addo Elephant National Park (March 2018).

\begin{tabular}{lcccc}
\hline Locality & Total & Healthy (\%) & Standing (\%) & Dead (\%) \\
\hline AENP Gardens & 18 & 50 & 17 & 33 \\
AENP Zuurberg & 30 & 20 & 27 & 53 \\
Summary & 48 & 27 & 27 & 46 \\
\hline
\end{tabular}

AENP, Addo Elephant National Park.

standing for 3 years without leaves, to produce new leaves. None of these replanted cycads were killed by the fire.

From the Zuurberg locality, it became clear that baboons caused further injury to cycads that had existing stem damage. It was noted that the baboons made no impact on the natural cycads occurring in the same area.

Baboons and other wildlife are part of the natural ecosystem where these cycads occur. Both Cousins and Witkowski (2017) and Nowak and Lee (2011) observed that the feeding and/or spreading of cycad seeds by baboons, monkeys, elephants, birds, fruit-eating bats, bush pigs and rodents is normal and characteristic of the local floral and faunal ecology. Interesting to note is that, according to Nowak and Lee (2011), monkeys have developed specialised foraging techniques that enable them to reach the newly-emerging soft leaves, which contain less of the toxin hydrogen cyanide, which is found in older leaves. Donaldson's (1995) historical records show that baboon damage to some female cones is insignificant $(<15 \%)$, thus ensuring the production of more than enough seeds and seedlings.

\section{Conclusion}

Undisturbed cycads are very slow growers, usually only producing one set of new leaves annually, but intervals between leaf production events can sometimes span several years (Cousins \& Witkowski 2017). The success or failure of this recovery project will only be visible after another 3 years. In the life cycle of these long-living cycads, 3 years is short, however the results that were recorded were remarkably positive and continued monitoring is imperative to record the long-term success of these individual plants after their reestablishment into AENP.

According to Dr. John Donaldson (South African National Biodiversity Institute [SANBI] cycad specialist - pers. comm., 18 Feburary 2015) and Mr. Werner Voigt (Kirstenbosch National Botanical Garden - pers. comm., 18 Feburary 2015), a survival rate of more than $20 \%$ (or nine) of cycad individuals will indicate that this project was successful. Overall, 13 individuals were classified as healthy and produced leaves, whilst 13 individuals were standing or lying on the soil surface (dormant) and could still grow. Unfortunately, 22 cycads died. The preliminary results of this study concur with Donaldson's Type 2 (Persister/reproducer) classification of these two cycad species (Donaldson 1995).

The results also indicate that the cycad individuals at the AENP gardens showed the best results. This is partially to be expected - apart from receiving more water in the garden, the climate was also less extreme than in the higher lying Zuurberg mountain range. Although these now garden 
cycads are not back in the natural habitat, they will hopefully produce seeds and suckers that could be used for reintroduction into the natural habitat. It is important to note that although we are dealing here with re-established cycads in the gardens and into the wild, the main aim should always be to relocate cycads into their natural environment. These cycads play an important role in the ecosystems' natural patterns and processes, with many organisms dependent on them (Cousins \& Witkowski 2017; Oberprieler 1999).

\section{Acknowledgements}

Without the dedication, passion, friendliness and hard work of so many people, this project would not have been possible. The previous Addo Elephant National Park Manager, Mr Mzwandile Mjadu and the previous Nature Conservation Manager, Mr John Adendorff, and Zelna Silcock (now Breytenbach) are thanked for immediate actions related to the recovery of these cycads. Apart from assisting with the treatment and replanting of the cycads, Mr Hans Von Gordon of the Addo (Port Elizabeth) Honorary rangers as well as the National Executive Committee (NEC) of the Honorary rangers, they were also financially involved with this project. Mr Louis and Queen Olivier also contributed material, time as well as expertise. Appreciation is extended to Dr John Donaldson and Mr Werner Voigt of SANBI, who gave valuable advice on the whole processes. Roxanne Erusan and Zelna Breytenbach assisted with monitoring and keeping me updated. The author would also like to thank Leslie Adriaanse of the University of South Africa library for assisting with obtaining some difficult references.

\section{Competing interests}

The author declares that no competing interests exist.

\section{Author's contributions}

I declare that I am the sole author of this research article.

\section{Funding information}

This research received no specific grant from any funding agency in the public, commercial, or not-for-profit sectors.

\section{Data availability statement}

It is a short note, data will remain with the author.

\section{Disclaimer}

The views and opinions expressed in this article are those of the author's and do not necessarily reflect the official policy or position of any affiliated agency of the authors.

\section{References}

Bezuidenhout, H., 2015, Recovery procedure of unearthed cycad trees in the Greater Addo Elephant National Park and adjacent areas April 2015, Internal Report 21/2015, Scientific Services, Kimberley, South African National Parks.

Bezuidenhout, H., Freitag-Ronaldson, S., Ferreira, S. \& Hofmeyr, M., 2017 Identification of proposed sustainability thresholds for key species: Encephalartos species (Cycads) in SANParks, Internal report 05/2017, Scientific Services, Kimberley South African National Parks.

Bezuidenhout, H. \& Hofmeyr, M., 2016, Memo on broad conceptual map on cycads (Encephalartos species) in SANParks, Internal Report 02/2016, Scientific Services, Kimberley Conservation Services Division, South African National Park.

Boyd, W.M., 1995. 'The translocation and re-establishment of priority Encephalartos species in the Transvaal', in The proceedings of the Third International Conference of Cycad Biology held in Pretoria, pp. 423-434. ISBN 9780620192286.

Cousins, S.R. \& Witkowski, E.T.F., 2017, 'African cycad ecology, ethnobotany and conservation: A synthesis', The Botanical Review 83, 152-194. https://doi. org/10.1007/s12229-017-9183-4

Department of Environmental Affairs, 2015, National strategy and action plan for the management of cycads, Publication of Environmental Affairs, Department: Environmental Affairs, Pretoria.

Donaldson, J.S., 1995, 'Understanding cycad life histories: An essential basis for successful conservation', in J.S. Donaldson (ed.), Cycad Society of South Africa cycad conservation in South Africa: Issues, priorities and actions, pp. 8-13, Cycad Society of South Africa, Claremont, ISBN 9780620190381.

Donaldson, J.S. (ed.), 2003, Cycads. Status survey and conservation action plan International Union for Conservation of Nature/SSC Cycad Specialist Group, International Union for Conservation of Nature, Gland, ix $+86 \mathrm{pp}$

Giddy, C., 1974, Cycads of South Africa, Purnell and Sons (S.A.) (PTY) LTD, Cape Town, $122 \mathrm{pp}$. ISBN 360002749.

Nowak, K. \& Lee, P.C., 2011, 'Consumption of cycads Encephalartos hildebrandtii by Zanzibar red colobus Procolobus kirkii', Journal of East African Natural History 100, 123-131. https://doi.org/10.2982/028.100.0108

Oberprieler, R.G., 1999, 'Systematics and evolution of the cycad-associated weevil genus Apinotropis Jordan (Coleoptera: Anthribidae)', African Entomology 7(1), 1-33.

Singh, K., 2012, 'Population dynamics of the Zuurberg cycad and the predicted impact of climate change', MSc. dissertation. Nelson Mandela Metropolitan University, Port Elizabeth.

Singh, K. \& Campbell, E.E., 2011, The Zuurberg cycads and predicted impacts of climate change, Research proposal for Addo Elephant National Park by the Department of Botany, Nelson Mandela Metropolitan University, Port Elizabeth.

Staatskoerant, 2017, 'National environmental management: Biodiversity Act, 2004 (ACT NO. 10 of 2004). Biodiversity management plan for eleven critically endangered and four endangered Encephalartos cycad species', Staatskoerant (40815), 275-349.

Van der Walt, K., 2014, Biodiversity management plan for 11 critically endangered and 4 endangered Encephalartos species, Report: Strategic Environmental Focus (S.E.F.), Lynnwood Ridge or SANBI, Silverton, Pretoria. 